Review Article

\title{
NUCLEOLOGENESIS AND NUCLEOLOTRANSFER IN MAMMALIAN OOCYTES: A REVIEW
}

\author{
Michal Benc ${ }^{1,2}$, Frantisek Strejcek ${ }^{3}$, Matej Murin ${ }^{3}$, Martin Morovic ${ }^{3}$, Stanislava Martinkova², \\ Dominika Jettmarova ${ }^{2}$, Lazo Pendovski ${ }^{4}$, Josef Fulka, Jr. ${ }^{2}$, Jozef Laurincik ${ }^{1,5}$ \\ ${ }^{1}$ Department of Zoology and Anthropology, Faculty of Natural Sciences, Constantine the \\ Philosopher University in Nitra, Nabrezie mladeze 91, 94974 Nitra, Slovak Republic \\ ${ }^{2}$ Institute of Animal Science, Pratelstvi 815, 10400 Prague - Uhrineves, Czech Republic \\ ${ }^{3}$ Department of Botany and Genetics, Faculty of Natural Sciences, Constantine the \\ Philosopher University in Nitra, Nabrezie mladeze 91, 94974 Nitra, Slovak Republic \\ ${ }^{4}$ Faculty of Veterinary Medicine-Skopje, Ss. Cyril and Methodius University in Skopje, \\ st. Lazar Pop-Trajkov 5-7, 1000 Skopje, Republic of Macedonia \\ ${ }^{5}$ Institute of Animal Physiology and Genetics AS CR, Rumburska 89, \\ 27721 Libechov, Czech Republic
}

Received 23 May 2017; Received in revised form 8 July 2017; Accepted 19 July 2017

\begin{abstract}
An effort to improve development potential of early embryos is one of the main goals of biotechnology in the area of reproductive biology with application in veterinary or human medicine. Recent observations of the function of nucleolus or rather its forms before, during and after the fertilisation or parthenogenetic activation show the key role(s) of nucleolus in the processes of early genome activation. The nucleolus is a subnuclear structure (organelle) mainly involved in regulation of transcription and translation. This organelle has been characterized in detail by immunofluorescence, cell transfection and proteomics. This data was, however, mostly obtained in nucleoli of differentiated eukaryotic cells. Much less is known about the nucleolar structural changes and related functional processes in growing and fully grown mammalian oocytes, zygotes and early cleavage stage embryos, especially in the context of embryonic genome activation. It has been shown, that nucleoli in mammalian oocytes and early embryos have several forms and functions, which vary during the oocyte growth and embryonic development. Certain functions have not been fully described or explained, yet. The method of enucleolation, which allows to remove nucleoli from the oocytes or to exchange nucleoli between oocytes or zygotes, together with their proteomic and structural analyses brought new information about functions of nucleoli in oocytes and early cleavage-stage embryos and allowed to explain some new key roles of nucleoli during oocyte maturation and early embryonic development.
\end{abstract}

Key words: nucleolus precursor body, nucleolus-like bodies, enucleolation, giant nucleoli

\section{INTRODUCTION}

The main goal of our review is to offer a compact view on nucleolus and all its forms in consideration of current knowledge and to suggest the best

\footnotetext{
Corresponding author: M.Sc. Michal Benc

E-mail address: benc.michal@gmail.com

Present address: Department of Zoology and Anthropology, Faculty of

Natural Sciences Constantine the Philosopher University in Nitra,

Nabrezie mladeze 91, 94974 Nitra, Slovak Republic

Phone: +421 915114034

Copyright: (C) 2017 Benc M. This is an open-access article published under the terms of the Creative Commons Attribution License which permits unrestricted use, distribution, and reproduction in any medium, provided the original author and source are credited.

Competing Interests: The authors have declared that no competing interests exist.

Available Online First: 1 August 2017

Published on: 15 October 2017

https://doi.org/10.1515/macvetrev-2017-0023
}

way of its application in the area of reproduction biology which can lead to an improvement of the development potential of early embryos used in veterinary or human medicine. The nucleolus is the intranuclear structure (organelle) in eukaryotic cells, usually located close to the nuclear membrane. It is a multifunctional organelle that is involved in rRNA synthesis and its posttranscriptional modifications, formation of ribosomes, cell cycle regulation, proliferation, chromosome segregation, reprogramming, common stress reaction, nuclear transport and many other functions. Interestingly, nucleoli in oocytes have several forms and functions, which vary during oocyte growth and early embryonic development. The typical 


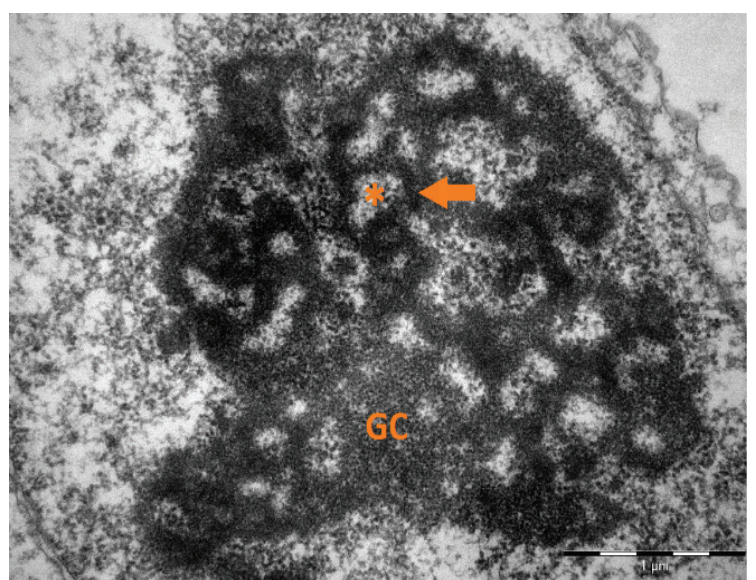

Figure 1a. An electronogram of nucleolar organization in somatic cell. The three nucleolar components are visible: the fibrillar centres (asterisks), the dense fibrillar component (arrow), and granular component (GC). Scale bar: $1.0 \mu \mathrm{m}$

differentiated nucleolus consists of fibrillar centers (FCs), dense fibrillar components (DFCs) and granular components (GCs) and can be found in somatic cells, stem cells, growing oocytes and in cells of advanced developing embryos (Fig. 1a).

\section{NUCLEOLI IN OOCYTES}

Very profound morphological and functional changes can be seen in nucleoli during oocyte

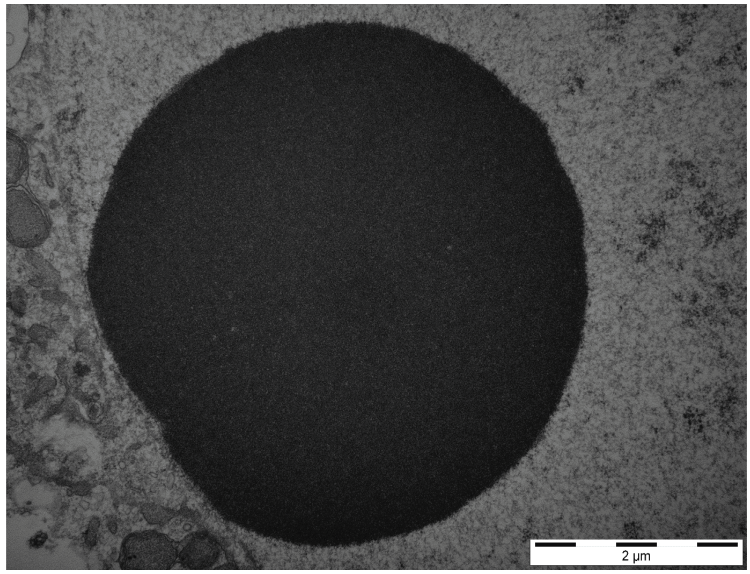

Figure 1b. An electronogram of NLB in fully grown porcine oocyte. Scale bar: $2.0 \mu \mathrm{m}$ growth. When the oocyte grows, the nucleolus has similar structure when compared to somatic cells, i.e. contains FC, DFC and GC with intensive RNA synthesis (1). By contrast, in fully grown oocytes the nucleolar structure differs completely. The nucleoli of fully grown oocytes are visible as dense compact structures composed almost exclusively of fibrillar material and are called as nucleolus-like bodies (NLBs) (Fig. 1b) (2).

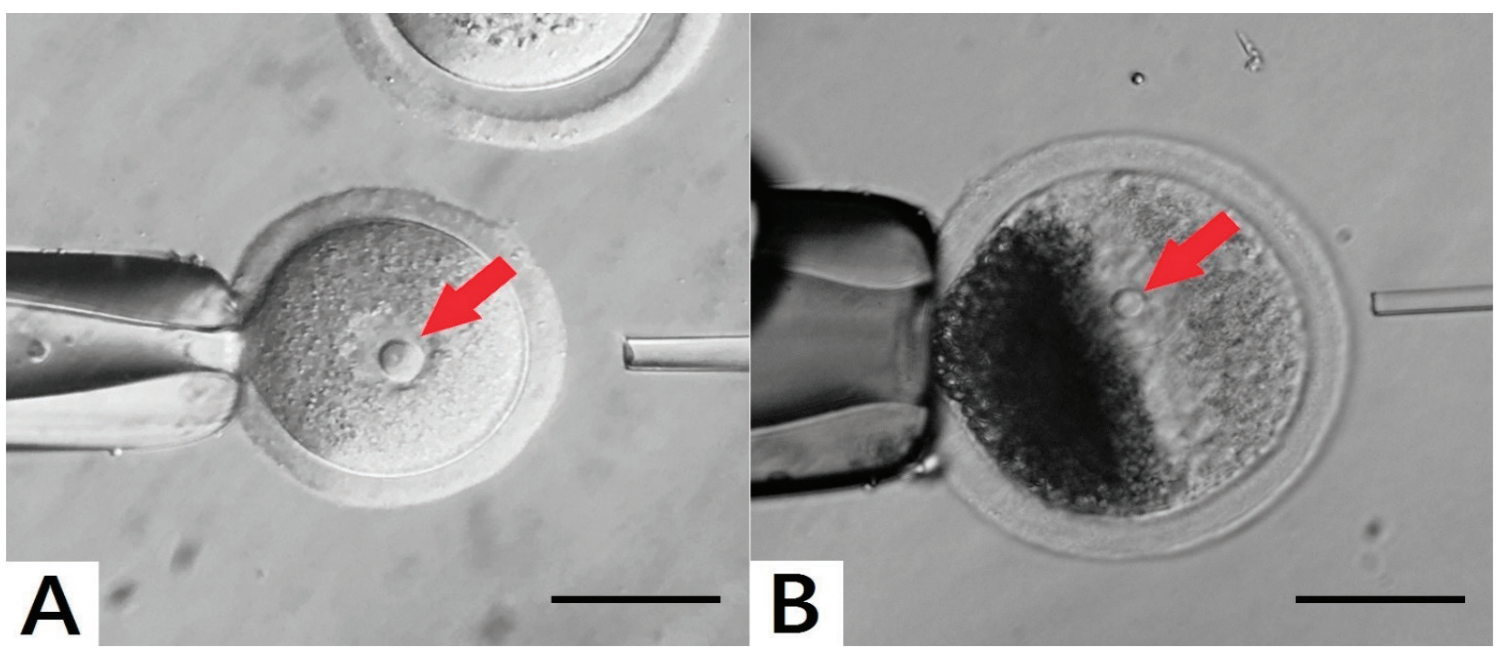

Figure 2. Visualisation of NLB in germinal vesicles (GV - red arrow). (A): Mouse oocyte. (B): As porcine oocytes contain many dark lipid particles they must be centrifuged in order to visualize GV with NLBs. The images were produced by the Olympus IX71 inverted microscope. The sample A was originated from mouse large antral follicle of CD - 1 IGS and the sample B was originated from porcine large antral follicle. Scale bar: $50.0 \mu \mathrm{m}$ 
In mouse and human oocytes, they are visible with conventional light microscopy (Fig. 2). Accordingly, RNA synthesis decreases in nucleoli of this oocyte developmental stage (3). The fully grown oocytes do not synthesize ribosomal RNA, but synthesis of the heterogeneous nuclear RNA continues until the resumption of meiosis (4).

Oocytes usually contain a single NLB within the nucleus, however, sometimes more than one NLB can be seen (Fig. 3). It is not known, if these oocytes have higher or lower competence to mature or develop after fertilization, but according to our preliminary studies they are not suitable for enucleolation by micromanipulation. It has been commonly accepted that oocyte and zygote NLB/ NPB serve as repository of material from which differentiated nucleoli in embryos are gradually formed during embryogenesis $(5,6)$. Recent observations have challenged this developmental biology dogma and showed that they are important only during a very short time period after fertilization $(7,8)$.

During the oocyte growth, profound chromatin and nucleolus modifications can be observed. In growing oocytes chromatin is dispersed throughout the germinal vesicle (GV) with no close association with the nucleolus (nonsurrounded nucleolus; NSN). On the other hand, in fully grown oocytes more intimate association between the NLB and chromatin can be seen (9). The chromatin in fully grown oocytes is in close contact with the NLB and forms the ring or the horseshoe around it - this is called the surrounded nucleolus. (SN) (Fig. 4) (10). Oocytes without close association with heterochromatin can be fertilized or parthenogenetically activated, even they form pronuclei but reach only the twocell stage (11).

It has been shown, that a single mouse NLB isolated from a fully grown oocyte contains approximately $1.6 \pm 0.3 \mathrm{ng}$ of proteins (12). However, very little is known about the proteomic composition of NLBs.

During the oocyte maturation, NLB dissolves concomitantly with germinal vesicle breakdown (GVBD) (13).

\section{NUCLEOLI IN ZYGOTES AND EARLY CLEAVAGE-STAGE EMBRYOS}

In comparison to immature oocytes at the $\mathrm{GV}$ stage, the zygotes typically contain several nucleoli in each pronucleus. During pronuclear development, these nucleoli fuse and form a single prominent structure (8). As it has been commonly accepted until recently that this structure is gradually transformed during subsequent embryonic development into typical tripartite nucleoli, it was also termed as so called "nucleolus precursor bodies - NPBs".

NPBs in zygotes and early cleavage-stage embryos are strictly of maternal origin, they are not formed de novo and they are essential for chromatin remodelling shortly post oocyte fertilization or parthenogenetic activation (14). Accordingly, they are not involved in embryonic ribosome production. Important results obtained by NLB and NPB transfer are summarized in the Figure 5 (1).

The NPB in zygotes or in early cleavage-stage embryos differ morphologically from nucleoli in more advanced embryos, stem cells and somatic cells (1). However, in many respects they are very similar to oocyte NLBs because they have dense fibrillar morphology. On the other hand, reticulated nucleoli in somatic cells and advanced embryo developmental stages have typical fibrillo-granular composition $(15,16,17)$.

At the two cell stage, mouse embryos become transcriptionally active and begin to synthesize rRNA $(18,19)$. Throughout this process, NPBs are gradually transformed into reticulated nucleoli (8).

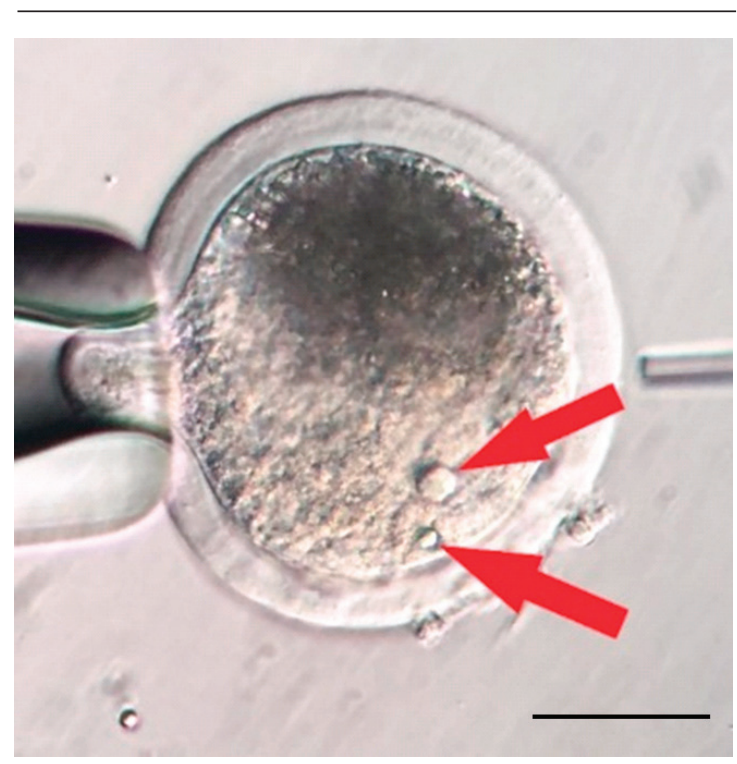

Figure 3. Two NLBs in GV stage of porcine oocyte. The image was produced by the Olympus IX71 inverted microscope. The sample was originated from porcine large antral follicle. Scale bar: $50.0 \mu \mathrm{m}$ 


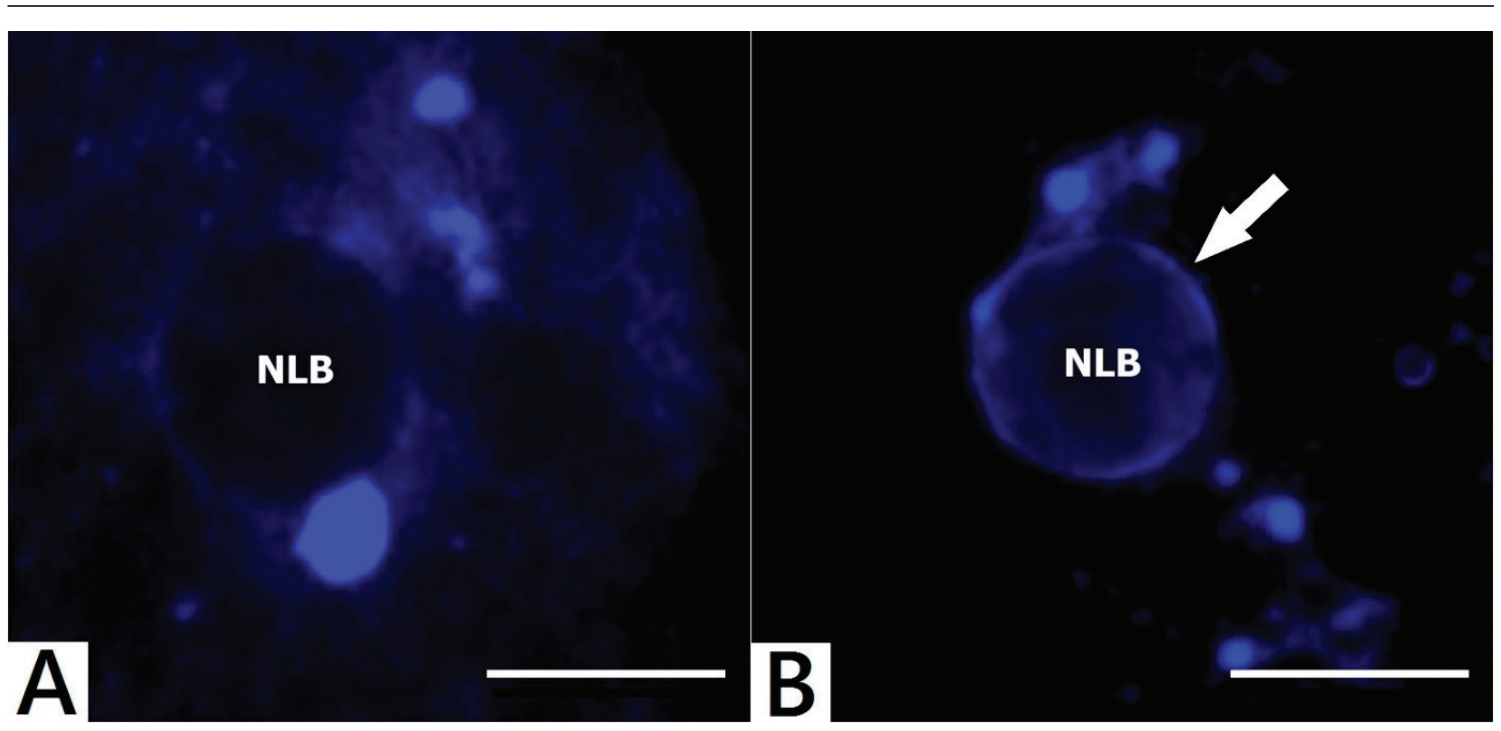

Figure 4. Distinct NLB and chromatin association in mouse oocytes. (A): NSN dispersed chromatin organisation. (B): SN chromatin organisation (chromatin - white arrow). The images were produced by the Olympus BX61 confocal fully automated microscope. Fluorescent staining of chromatin was made by Hoechst 33342 (Sigma 14533). All samples were originated from mouse large antral follicles of CD - 1 IGS. Scale bar: $10.0 \mu \mathrm{m}$

\section{NUCLEOLI IN DIFFERENTIATED CELLS}

Typical differentiated nucleolus in somatic cells is an intranuclear organelle consisting of FC, FCS and GC (Fig. 1a) (23). The main function of these nucleoli is the participation on synthesis of ribosomal RNAs (rRNAs), except for 5S RNA. This synthesis is catalysed by RNA polymerase I, primarily located in the nucleolus (13). Other functions of these nucleoli include the control of cell cycle progression, genome maintenance, differentiation and regulation of DNA damage responses differentiation, etc. (1). rRNA is a major structural and functional component of ribosomes. It is created by transcription of rDNA. The cell contains four types of rRNA, which are $120-5000$ base pairs length and present $80 \%$ of all RNA (24).

During the early embryonic development, NLB changes its fibrillar composition into a tripartite one. This process is associated with the resumption of rRNA synthesis (1).

\section{NUCLEOLOTRANSFER AND ITS APPLICATION}

Whilst the somatic cell nucleoli were analysed in detail, very little is known about the composition of NLBs (NPBs). This is a consequence of difficult isolation of this structure from GV oocytes (or zygotes). This has been solved when Fulka, Jr. et al. invented the method of microsurgical removal of NLB from fully grown oocytes called "the enucleolation" (3).

Shortly after the enucleolation, the volume of isolated NLB rapidly decreases and NLBs dissolve in the medium. However, if NLBs are removed from GVs as so called "nucleoloplasts" (i.e. NLB is enclosed with a small volume of the cytoplasm and cytoplasmic membrane), NLB is protected and does not dissolve. All steps of the procedure are described in detail in the Figure 6. It is very important to note, that the isolated NLB is not enclosed with a residual DNA. This was verified by labelling the nucleoloplasts with anti-trimethyl $\mathrm{H} 4$ / K20 antibody or staining by Hoechst 33342 (12).

As mentioned above, the collection of sufficient number of NLBs which can be collected in one experiment is rather complicated, i.e. the enucleolation needs certain skills, NLBs can be very easily lost due to their small diameter or if not collected as nucleoloplasts they dissolve rapidly in the medium. This problem has been solved by producing so called "giant NLBs" (Fig. 7) (12). The giant nucleoli are well visible, relatively easily handled and collected and thus ready for further analyses (12).

Usually, the manipulation medium contains bovine serum albumin (BSA), which may be a problem for further, i.e. proteomic analyses. Therefore, it can be replaced with polyvinyl 
alcohol (PVA) (12). According to our experiences, for enucleation, the M2 medium (Zenith Biotech ZFM2-050; Czech Republic) supplemented with PVA (Sigma P8136; Czech Republic) is superior to M2 medium (Zenith Biotech ZFM2-050; Czech
Republic) supplemented with BSA (Sigma A3311; Czech Republic), as the cytoplasmic membrane appears to be more compact. The enucleolation from zygotes is similar to the method reported for the oocytes (8).

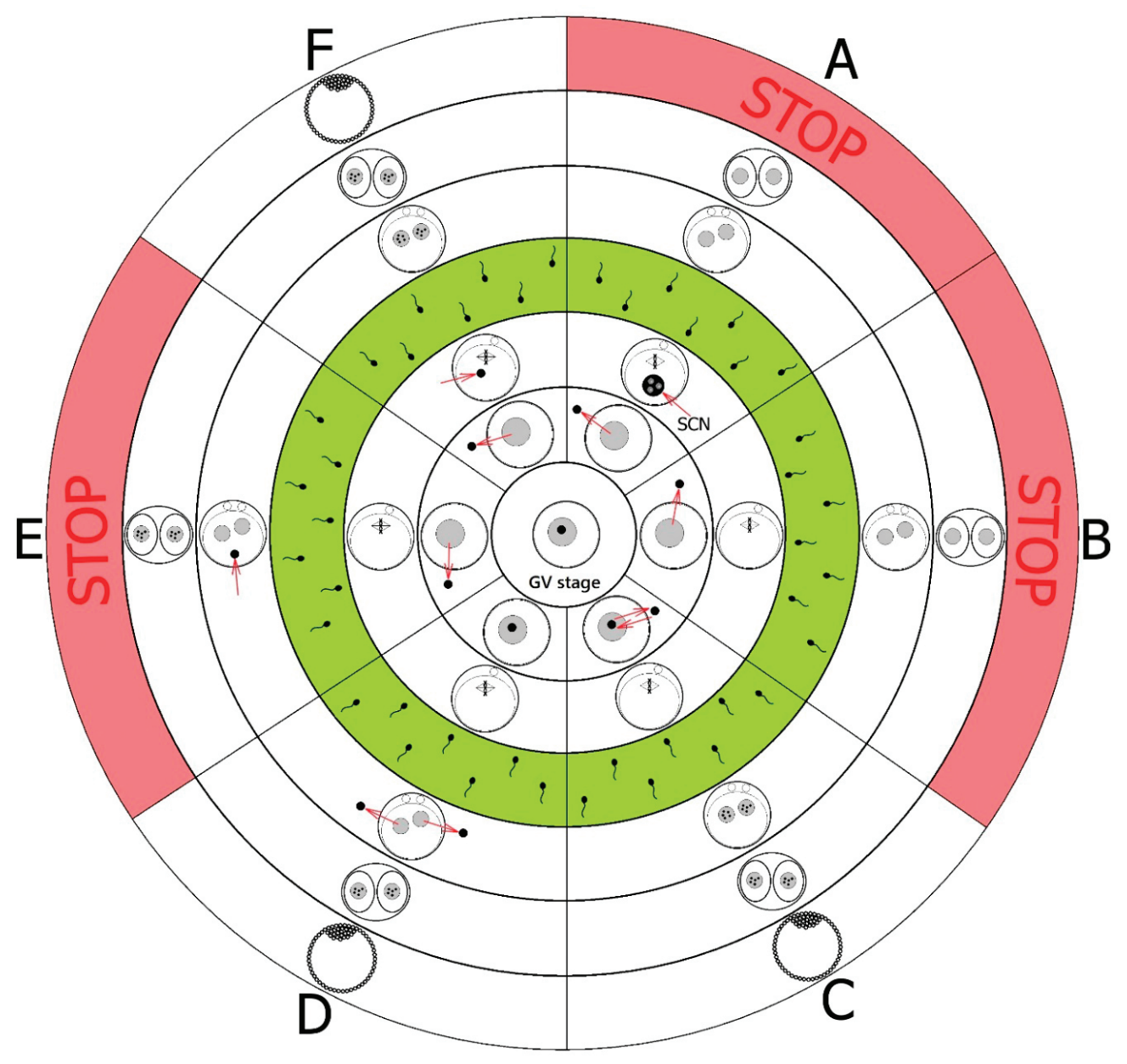

Figure 5. Scheme of NLB transfer (nucleolotransfer). SCN - somatic cell nucleus with its nucleolus; Green circle - IVF or parthenogenetic activation; STOP - no development. (A): If NLBs were replaced by somatic cell nucleoli (SCN), the embryo development was stopped and no NPBs in pronuclei were found after parthenogenetic activation or IVF $(14,20,21)$. (B): Oocytes from which NLBs were removed have matured to metaphase II, however after parthenogenetic activation or IVF, no NPBs in pronuclei were found and the embryo development was stopped at the two-cell stage (14). (C): If NLBs were re-injected immediately after the enucleolation, these oocytes matured to metaphase II and after parthenogenetic activation or IVF, NPBs in pronuclei were formed and embryos developed to full term (14). (D): When NPBs were removed from late zygotes, no NPBs were detected in pronuclei or nuclei of enucleolated zygotes or in two-cell embryos. However, later (approximately at the four-cell stage) these embryos formed nucleoli de novo and the embryos have developed into the blastocyst stage after parthenogenetic activation or IVF (8). (E): If NLBs were removed from oocytes and introduced back into more advanced parthenogenetic or IVF embryos (originated from enucleolated oocytes, i.e. more than $8 \mathrm{hrs}$ post activation or IVF), the embryo development was stopped at the two-cell stage (22). (F): If NLBs were removed from oocytes and introduced back into less advanced embryos (without NPBs) post parthenogenetic activation or IVF (i.e. less than $7 \mathrm{hrs}$ ), NPBs in pronuclei were seen and embryos developed to full term $(14,22)$ 


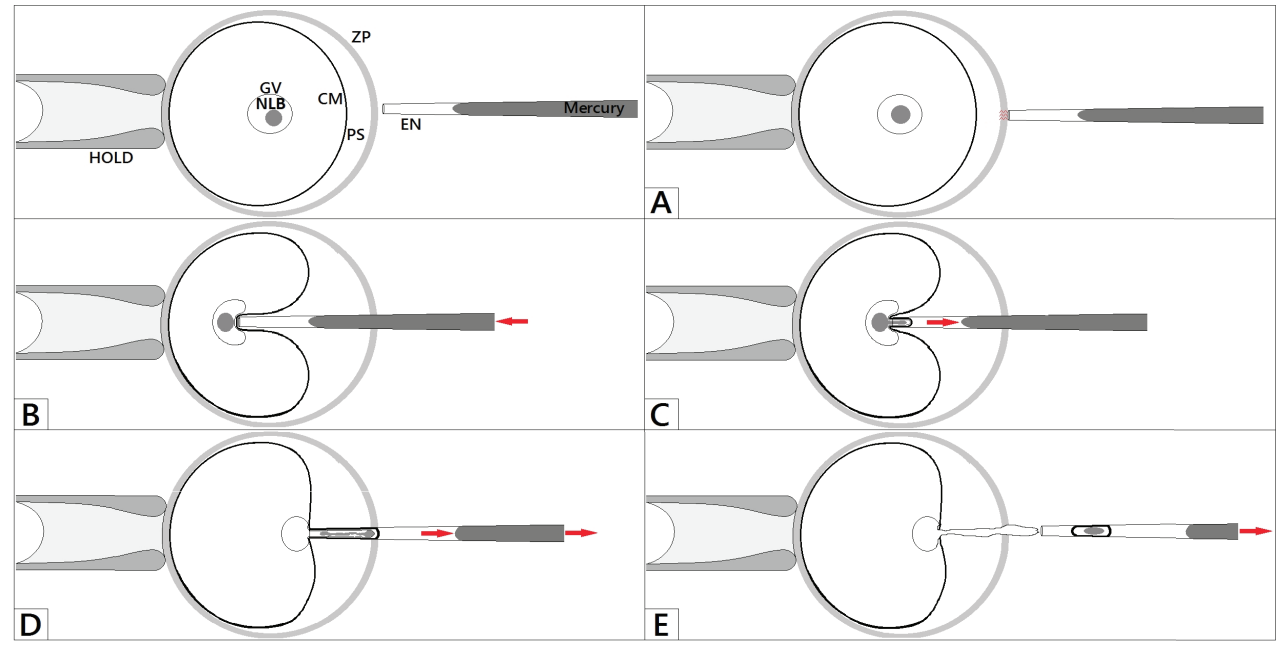

Figure 6. Process of enucleolation. HOLD - holding pipette, EN - enucleolation pipette, $\mathbf{Z P}$ - zona pellucida, PS - perivitelline space, CM - cytoplasmic membrane, GV - germinal vesicle, NLB. (A): Oocyte is fixed in the stable position by applying the suction in holding pipette. The enucleolation pipette is positioned close to the NLB and penetrates through the zona pellucida. (B): The enucleolation pipette aspirates the NLB, but the cytoplasmic membrane is still intact. (C): The NLB is slowly and gently aspirated into the enucleolation pipette. (D): The enucleolation pipette is then slowly withdrawn from the oocyte. (E): As soon as the enucleolation pipette is outside, additional suction is applied and the NLB slowly penetrates the germinal vesicle like a sand in a sand-glass

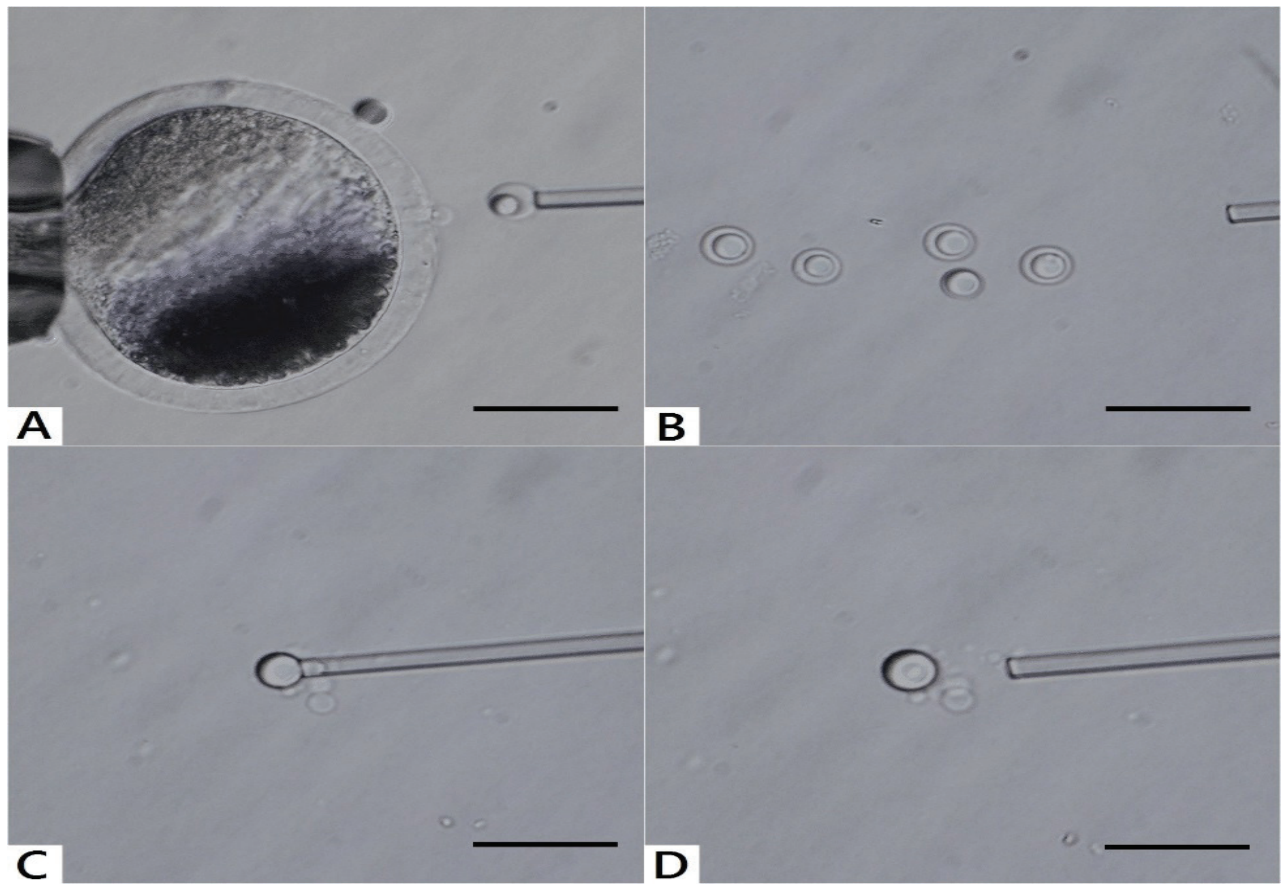

Figure 7. Enucleolation and production of giant NLB. (A, B): The first step of this process is the microsurgical removal of nucleoli from fully grown oocytes as nucleoloplasts. $(\mathbf{C})$ : Then, nucleoloplasts are aspirated into an enucleolation pipette and the piezo pulses are applied. Consequently, the nucleoloplast envelope (membrane) is broken down and NLB is freed into the manipulation medium. These steps must be then repeated very quickly with remaining nucleoloplasts. (D): Thereafter, the nucleoli are fused when contact between them is achieved and the giant NLB is produced. The image was produced by the Olympus IX71 inverted microscope. Microsurgical processes were made by Narishige micromanipulators with piezo unit (Prime Tech, Tsuchiura, Ibaraki, Japan). The sample was originated from porcine large antral follicle. Scale bar: $50.0 \mu \mathrm{m}$ 


\section{CONCLUSION}

It has been demonstrated very recently that zygotic NPBs are exclusively of maternal origin and are essential only shortly after the IVF or parthenogenetic activation. Thus they are probably not that essential for more advanced embryonic development. This enables much better understanding of the role(s) NLBs (NPBs) in the processes of genome activation and early embryonic development. We suppose, that deeper knowledge of the NLB/NPB composition and their role(s) in the processes of early genome activation, together with excellent encompassment of microsurgical methods of substitution of the NLBs/NPBs, may give rise to an improvement of development potential of early embryos. This will be crucial for improvement of the quality of the oocytes used in reproductive veterinary or human medicine.

\section{CONFLICT OF INTEREST STATEMENT}

The authors declared that they have no potential conflict of interest with respect to the authorship and/or publication of this article.

\section{ACKNOWLEDGMENT}

This work was supported by Slovak Research and Development Agency under the contract No. APVV14-0001, and also by the projects CZ.02.1.01/0.0/0.0/15 _003/0000460, VEGA 1/0022/15, VEGA 1/0327/16 and Research Center AgroBioTech built in accordance with the project Building Research Centre "AgroBioTech" ITMS 26220220180. JF Jr. and DJ are supported from GACR 17-08605S.

\section{REFERENCES}

1. Fulka, H., Kyogoku, H., Zatsepina, O., Langerova, A, Fulka, J. Jr. (2015). Can nucleoli be markers of developmental potential in human zygotes? Trends Mol Med. 21 (11): 663-672.

https://doi.org/10.1016/j.molmed.2015.09.005

PMid:26494190

2. Lefèvre, B. (2008). The nucleolus of the maternal gamete is essential for life. Bioessays 30, 613-616. https://doi.org/10.1002/bies.20774

PMid:18536024
3. Fulka, J. Jr., Moor, R. M., Loi, P., Fulka, J. (2003). Enucleolation of porcine oocytes. Theriogenology 59, 1879-1885. https://doi.org/10.1016/S0093-691X(02)01226-8

4. Rodman, T. C., Bachvarova, R. (1976). RNA synthesis in preovulatory mouse oocytes. J. Cell Biol. 70, 251-257.

https://doi.org/10.1083/jcb.70.1.251

PMid:932101

5. Chouinard, L. A. (1975). A light- and electronmicroscope study of the oocyte nucleus during development of the antral follicle in the prepubertal mouse. J. Cell Sci. 17, 589-615. PMid:1141388

6. Chouinard, L. A. (1971). A light- and electronmicroscope study of the nucleolus during growth of the oocyte in the prepubertal mouse. J. Cell Sci. 9, 637-663. PMid:4112474

7. Fulka, H., Langerova, A. (2014). The maternal nucleolus plays a key role in centromere satellite maintenance during the oocyte to embryo transition. Development 141, 1694-1704.

https://doi.org/10.1242/dev.105940

PMid:24715459

8. Kyogoku, H. Fulka, J. Jr., Wakayama, T., Miyano, T. (2014). De novo formation of nucleoli in developing mouse embryos originating from enucleolated zygotes. Development 141, 2255-2259.

https://doi.org/10.1242/dev.106948

PMid:24803589

9. Christians, E., Boiani, M., Garagna, S., Dessy, C., Redi, C. A., Renard, J. P., Zuccotti, M. (1999). Gene expression and chromatin organization during mouse oocyte growth. Dev Biol. 207 (1): 76-85. https://doi.org/10.1006/dbio.1998.9157 PMid:10049566

10. Bachant, J. B., Elledge, S. J. (1999). Cell cycle: Mitotic treasures in the nucleolus. Nature 398, 757-758. https://doi.org/10.1038/19641 PMid:10235256

11. Inoue, A. Nakajima, R., Nagata, M., Aoki, F. (2008). Contribution of the oocyte nucleus and cytoplasm to the determination of meiotic and developmental competence in mice. Hum. Reprod. 23, 1377-1384. https://doi.org/10.1093/humrep/den096 PMid:18367455

12. Fulka, H., Martinkova. S., Kyogoku, H., Langerova, A., Fulka, J. Jr. (2012). Production of giant mouse oocyte nucleoli and assessment of their protein content. J. Reprod. Dev. 58, 371-376.

https://doi.org/10.1262/jrd.2011-004

PMid:22293324 
13. Snustad, D. P., Simmons, M. J. (2009). Principles of genetics. John Wiley \& Sons, UK, 18

14. Ogushi, S., Palmieri, C., Fulka, H., Saitou, M., Miyano, T., Fulka, J. Jr. (2008). The maternal nucleolus is essential for early embryonic development in mammals. Science 319, 613-616. https://doi.org/10.1126/science.1151276 PMid:18239124

15. Flechon, J. E., Kopecny, V. (1998). The nature of the ,nucleolus precursor body" in early preimplantation embryos: a review of fine-structure cytochemical, immunocytochemical and autoradiographic data related to nucleolar function. Zygote 6, 183-191. https://doi.org/10.1017/S0967199498000112 PMid:9770784

16. Derenzini, M., Thiry, M., Goessens, G. (1990). Ultrastructural cytochemistry of the mammalian cell nucleolus. J. Histochem. Cytochem. 38, 1237-1256. https://doi.org/10.1177/38.9.2201735 PMid:2201735

17. Olson, M. O. J., Dundr, M., Szebeni, A. (2000). The nucleolus: an old factory with unexpected capabilities. Trends Cell Biol. 10, 189-196. https://doi.org/10.1016/S0962-8924(00)01738-4

18. Schultz, R. M. (2002). The molecular foundations of the maternal to zygotic transition in the preimplantation embryo. Hum. Reprod. Update. 8, 323-331.

https://doi.org/10.1093/humupd/8.4.323

PMid:12206467.

19. Zatsepina, O., Baly, C., Chebrout, M., Debey, P. (2003). The step-wise assembly of a functional nucleolus in preimplantation mouse embryos involves the Cajal (coiled) body. Dev. Biol. 253, 66-83.

https://doi.org/10.1006/dbio.2002.0865

PMid:12490198
20. Wakayama, T., Rodriguez, I., Perry, A. C., Yanagimachi, R., Mombaerts, P. (1999). Mice cloned from embryonic stem cells. Proc. Natl. Acad. Sci. U.S.A. 96, 14984-14989.

https://doi.org/10.1073/pnas.96.26.14984

PMid:10611324 PMCid:PMC24759

21. Wakayama, T., Yanagimachi, R. (2001). Mouse cloning with nucleus donor cells of different age and type. Mol. Reprod. Dev. 58, 376-383.

https://doi.org/10.1002/1098-

2795(20010401)58:4<376::AID-MRD4>3.0.CO;2-L

22. Ogushi, S., Saitou, M. (2010). The nucleolus in the mouse oocyte is required for the early step of both female and male pronucleus organization. J. Reprod. Dev. 56, 495-501.

ttps://doi.org/10.1262/jrd.09-184H

PMid:20519829

23. Hernandez-Verdun, D., Roussel, P., Thiry, M., Sirri, V., Lafontaine, D. L. (2010). The nucleolus: structure/function relationship in RNA metabolism. Wiley Interdiscip Rev RNA. 1 (3): 415-431.

https://doi.org/10.1002/wrna.39

PMid:21956940

24. Koolman, J., Röhm, K. H. (2009). Taschenatlas biochemie des menschen. Georg Thieme Verlag Stuttgart, New York, 66.

https://doi.org/10.1055/b-002-15439 